\title{
First recorded case of paramyxovirus infection introduced into a healthy snake collection in Croatia
}

\author{
Jelena Prpic ${ }^{1 *}$, Tomislav Keros ${ }^{1}$, Maja Lang Balija ${ }^{2,3}$, Dubravko Forcic $^{2,3}$ and Lorena Jemersic ${ }^{1}$
}

\begin{abstract}
Background: In the present study, we describe the first paramyxovirus infection in a snake collection in Croatia caused by an introduction of new snakes that were not previously tested and didn't show any signs of disease.

Case presentation: In less than a month after introduction into a healthy colony, new snakes began to show respiratory symptoms (i.e. mouth opening, wheezing, etc.) and died within a month and a half after antibiotic therapy was applied. The same symptoms and a high mortality rate were then observed in in-contact snakes from other collections belonging to different snake families.

Conclusions: Two entries of new snakes in different time periods were recorded and recognized as possible sources of infection. We stress the need for veterinary health control and monitoring of snakes prior to transportation as well as implementing obligatory quarantine measures to minimize the risk of infection among newly established snake groups.
\end{abstract}

Keywords: Snake, Paramyxovirus, Nested RT-PCR, Phylogenetic characterization, Infection, Croatia

\section{Background}

Paramyxoviruses (PMV) are negative sensed single stranded RNA viruses with a helical nucleocapsid packaged in a pleomorphic envelope and are classified as members of the Paramyxoviridae family, genus Ferlavirus [5, 6, 11]. According to studies based on partial sequences of $\mathrm{L}$, $\mathrm{HN}$, and $\mathrm{U}$ genes $[1,11,3]$, members of the genus Ferlavirus are grouped into three subgroups, subgroups $\mathrm{A}, \mathrm{B}$ and $\mathrm{C}$. There are numerous reports of Ferlavirus isolation worldwide from zoological and private collections. Up to now, the occurrence of PMVs has been detected in several snake (sub) families: Colubridae, Elapidae, Viperidae, Crotalidae, Boidae and Pythonidae [4, 7, 9, 11]. The purchase and introduction of new reptiles into an established collection is of high risk in regards to disease spread and manifestation as well as a probable cause of a higher mortality rate. It has been demonstrated that viral infections such as inclusion body disease (IBD) and PMV [12], as well as some bacterial infections, represent a significant

\footnotetext{
* Correspondence: balatinec@veinst.hr

${ }^{1}$ Croatian Veterinary Institute, Savska cesta 143, 10000 Zagreb, Croatia

Full list of author information is available at the end of the article
}

risk when latently infected snakes are introduced into healthy snake collections [13].

The objective of this study was to detect PMV RNA in samples derived during 2015 from a collection of exotic snakes showing signs of disease. Furthermore, sequencing of a highly conserved fragment within PMV L-gene region was performed to define the genetic heterogeneity of the virus isolates and to compare the sequences with previously described ones from the GenBank. The aim was to retroactively define the probable sources of infection. In consensus with earlier publications $[8,10]$ we used a nested RT-PCR protocol targeting the L-gene [2] as the most sensitive method currently available for basic diagnostics of PMV infection.

\section{Case presentation}

In less than a month after introduction of Dendroaspis jamesoni jamesoni (purchased from a private keeper from the Czech Republic in September 2014) into a healthy colony, the mamba began to show respiratory symptoms (i.e. mouth opening, wheezing, etc.) and died within a month and a half after antibiotic therapy (Marbocyl for 10 days) was applied. The same symptoms and a high mortality rate were then observed in other 
snakes from collections belonging to different snake families. In February 2015 the breeder purchased new snakes and introduced them into the collection. One pair (male and female) of Dendroaspis viridis (caught in the wild in Ghana) was purchased from a private keeper from the Czech Republic, whereas snakes Bitis nasicornis were purchased from Poland. Dendroaspis viridis didn't show any respiratory symptoms but was in a poor condition and died within a month and a half. The snake owner noticed the same clinical signs and a high mortality rate in other snakes from his collection belonging to different snake families. Autopsy showed signs of fibrotic pneumonia.

Lung tissue (CRO-PMV-1 to CRO-PMV-6 and CROPMV-12) and tracheal and cloacal swab samples (CROPMV-7 to CRO-PMV-11) were collected (Table 1). Approximately, $0.1 \mathrm{~g}$ of lung samples were homogenized in $1 \mathrm{~mL}$ of phosphate-buffered saline (PBS; pH 7.4) and then vortexed for $1 \mathrm{~min}$ and centrifuged for $15 \mathrm{~min}$ at $1000 \times g$. Tracheal and cloacal swabs were taken by moistened cotton-tipped sterile swabs and sterile MEM$\mathrm{H}$ from the snakes that began to show the signs of disease. After filtration $(0.45 \mu \mathrm{m})$, swab samples were inoculated into a Vero cell culture and propagated for up to two passages. Vero cell culture was maintained in minimal essential medium with Hank's salts (MEM-H), supplemented with $10 \%$ foetal calf serum (FCS) and $50 \mathrm{mg} /$ $\mathrm{ml}$ neomycin and the incubation was carried out at $32^{\circ}$ $\mathrm{C}$ in a medium with added $2 \%$ FCS until a cytopathic effect was observed. An amount of $100 \mu \mathrm{L}$ of each homogenized lung supernatant, swab sample and cell culture sample was used for viral RNA purification using iPrep Total RNA Kit (Invitrogen, USA) according to the manufacturer's instructions.

The amplification of PMV L-gene fragments was adopted from previously published methodology [2]. One-step reverse transcription PCR and nested PCR assays for the amplification of 627-bp and 566-bp long products of Lgene, respectively, were performed using SuperScript III One-Step RT-PCR with PlatinumTaq (Invitrogen, USA) and PlatinumBlue PCR SuperMix (Invitrogen, USA) using primer pairs and the amplification procedure described by Ahne et al. [2]. PCR products were separated by agarose gel electrophoresis in a $1.5 \%$ agarose gel stained with ethidium bromide and visualized by UV transillumination. Twelve gel purified PCR amplicons (Wizard SV gel and PCR Clean up system, Promega, USA) derived from 10 snakes were sequenced directly (Macrogen Inc., Amsterdam, The Netherlands). To determine the phylogenetic grouping of the obtained sequences (GenBank KU207735 to KU207746) the prototype PMV sequences [11] were retrieved from GenBank. Also, similar sequences obtained using BLAST algorithm (http://www.ncbi.nlm.nih.gov) were included in the study. Sequences were aligned using ClustalX, version 2.0 [16] and analyzed by MEGA 5 [15].

\section{Discussion}

The amplification of PMV L-gene region from all samples (CRO-PMV-1 to CRO-PMV-12) resulted in clear PCR products with the expected molecular size. The phylogenetic relationship analysis of the obtained sequences showed that all analyzed PMV sequences grouped into group B (Fig. 1) of the proposed genus Ferlavirus [11]. Sequences

Table 1 Animals used in the study

\begin{tabular}{|c|c|c|c|}
\hline Host & Origin of snakes & Sample/time of death & Label \\
\hline Crotalus m. molossus & Imported in September 2014 from Germany & $\begin{array}{l}\text { Lung tissue } \\
\text { March } 2015\end{array}$ & CRO-PMV-1 \\
\hline Crotalus m. molossus & Imported in September 2014 from Germany & $\begin{array}{l}\text { Lung tissue } \\
\text { August } 2015\end{array}$ & CRO-PMV-2 \\
\hline Crotalus m. pyrrus & Imported in 2013 from Germany & $\begin{array}{l}\text { Lung tissue } \\
\text { August } 2015\end{array}$ & CRO-PMV-5 \\
\hline Dendroaspis viridis & Imported in February 2015 from Czech Republic & $\begin{array}{l}\text { Lung tissue } \\
\text { April } 2015\end{array}$ & CRO-PMV-3 \\
\hline Dendroaspis j. jamesoni & Imported in September 2014 from Czech Republic & $\begin{array}{l}\text { Lung tissue } \\
\text { April } 2015\end{array}$ & CRO-PMV-4 \\
\hline Bitis atropos & Imported in 2012 from South Africa & $\begin{array}{l}\text { Lung tissue } \\
\text { September } 2015\end{array}$ & CRO-PMV-6 \\
\hline Bitis nasicornis & Imported in February 2015 from Poland & $\begin{array}{l}\text { Lung tissue } \\
\text { August } 2015\end{array}$ & CRO-PMV-12 \\
\hline Morelia viridis & Imported in 2009 from Croatia & $\begin{array}{l}\text { Tracheal/ cloacal swab } \\
\text { October } 2015\end{array}$ & $\begin{array}{l}\text { CRO-PMV-7 } \\
\text { CRO-PMV-8 }\end{array}$ \\
\hline Crotalus I. klauberi & Imported in 2014 from Austria & $\begin{array}{l}\text { Tracheal/ cloacal swab } \\
\text { October } \\
2015 .\end{array}$ & $\begin{array}{l}\text { CRO-PMV-9 } \\
\text { CRO-PMV-10 }\end{array}$ \\
\hline Aspidites melanocephala & Imported in 2011 from Germany & $\begin{array}{l}\text { Tracheal swab } \\
\text { Still alive }\end{array}$ & CRO-PMV-11 \\
\hline
\end{tabular}




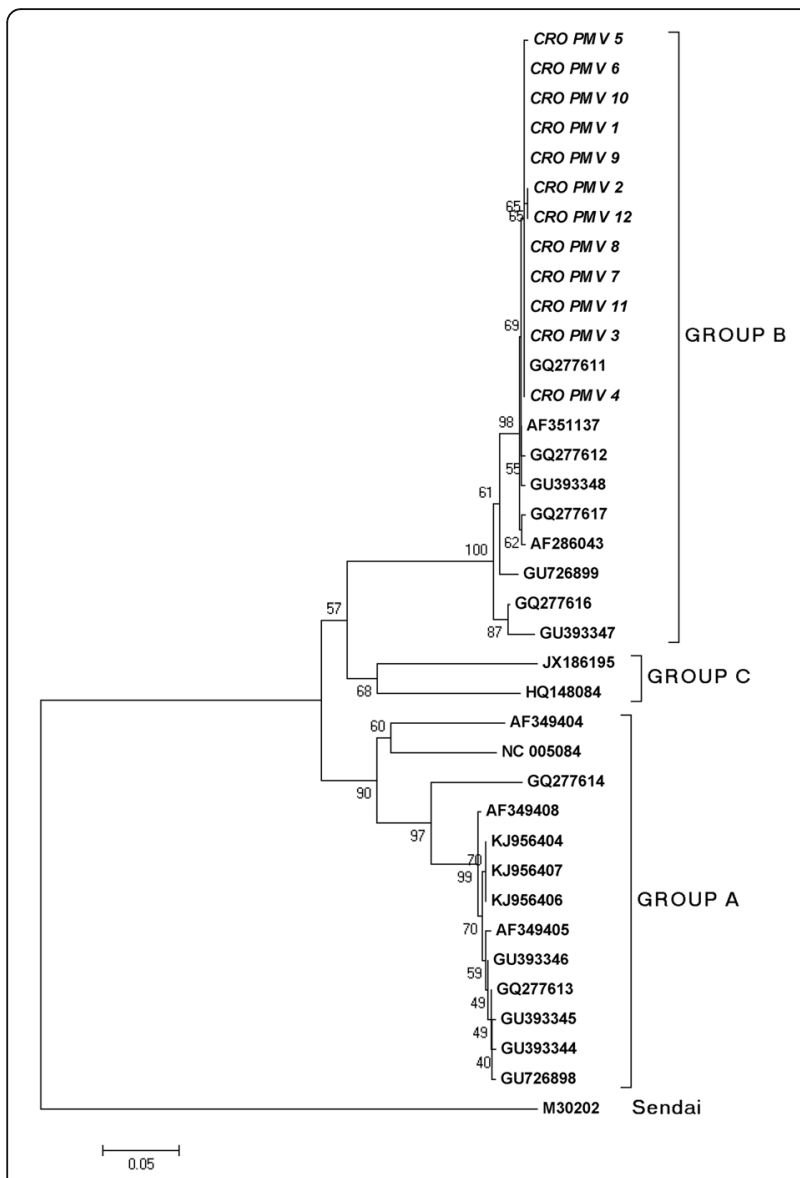

Fig. 1 Neighbor-joining phylogenetic tree obtained by the analysis of the partial L-gene region of PMV strains derived from snake (bold, italic) samples in Croatia. Genetic distances were calculated using the Kimura two-parameter method. Genotype reference sequences (bold) were adopted from Papp et al., [11]. Bootstrap values are presented next to tree nodes. The bar represents 0.05 nucleotide substitution per site
CRO-PMV-1, CRO-PMV-3, CRO-PMV-4 and CRO-PMV6 to $\mathrm{CRO}-\mathrm{PMV}-11$ were found to be $100 \%$ identical among themselves in the $443 \mathrm{nt} \mathrm{L-gene} \mathrm{region,} \mathrm{while} \mathrm{sequences}$ CRO-PMV-2, CRO-PMV-12 and CRO-PMV-5 differed from these sequences in one nucleotide on positions 241 and 413, respectively. Nucleotide differences in 443 nt long region coding for 143 aa long polypeptide caused differences in aa composition (aa position 81 and 138). The valine replacement by the phenylalanine residue at position 81 of the 143 aa long L-polypeptide doesn't show any effect on protein structure and function, since both of these amino acids are hydrophobic. However, the replacement of hydrophilic glutamine by the basic arginine residue at position 138 could have an impact on viral characteristics, as has been observed in Newcastle disease virus when the replacement of glutamine by the arginine residue in F protein reduced viral replication and attenuated the virus pathogenicity [14].
All Croatian PMV isolates showed high nucleotide identity with sequences of PMV isolates from Germany (GQ277611, AF351137, GQ277612, GU393348 and GQ277617) and Austria (AF286043).

According to the data gained, there are two possible sources of infection. The first source of infection was Dendroaspis jamesoni jamesoni (CRO-PMV-4) imported from the Czech Republic in September 2014. The disease spread to Crotalus molosus molosus (CRO-PMV 1). Virus sequences isolated from these snakes are mutually identical. The second sources of infection were Dendroaspis viridis (CRO-PMV-3) and Bitis nasicornis (CRO-PMV-12) that were introduced into the collection in February 2015. We can presume that the disease spread from Bitis nasicornis (CRO-PMV-12) to Crotalus molosus molosus (CRO-PMV2) since the virus sequences isolated from these snakes are mutually identical. However, the source of infection for the strain isolated from Crotalus molosus Pyrrus (CRO-PMV-5) could not be identified. We presume that point mutations could be initiated by multiple passages in vivo originating from previously introduced clusters since this snake was in the colony since 2013. The passages in Vero cells couldn't be responsible for the observed mutations, since the sequences from swab samples and cell culture supernatants were $100 \%$ identical.

\section{Conclusions}

Our results imply that the infection was introduced into the healthy collection by new snakes that were not previously tested or showing signs of disease. Since no vaccine is presently commercially available, basic veterinary health checks and quarantine measures are of great importance to minimize the risk of infection among newly established snake groups.

\section{Acknowledgements}

The authors are grateful to Mr. Neven Vrbanic for providing the experimental samples and for excellent technical assistance in handling snakes.

\section{Availability of data and materials}

All data generated or analysed during this study are included in this manuscript.

\section{Authors' contributions}

JP made substantial contributions to conception and design, acquisition of data, analysis and interpretation of data. TK, DF, MLB, LJ have been involved in drafting the manuscript or revising it critically for important intellectual content. All authors read and approved the final manuscript.

\section{Competing interests}

The authors declare that they have no competing interests.

\section{Consent for publication \\ Not applicable.}

\section{Ethics approval and consent to participate}

Taking swabs from live snake and sampling tissue of dead animals is done in accordance with good veterinary practice. On the other side, Croatian legislation is harmonized with the Code of good veterinary practice. (https:// ec.europa.eu/digital-agenda/en/content/federation-veterinarians-europe- 
code-good-veterinary-practice)(http://www.fve.org/news/publications/pdf/ gvp.pdf).

\section{Publisher's Note}

Springer Nature remains neutral with regard to jurisdictional claims in published maps and institutional affiliations.

\section{Author details}

'Croatian Veterinary Institute, Savska cesta 143, 10000 Zagreb, Croatia.

${ }^{2}$ Centre for Research and Knowledge Transfer in Biotechnology, University of Zagreb, Rockefellerova 10, 10000 Zagreb, Croatia. ${ }^{3}$ Center of Excellence for Viral Immunology and Vaccines, CERVirVac, Zagreb, Croatia.

Received: 5 November 2016 Accepted: 30 March 2017

Published online: 08 April 2017

\section{References}

1. Abbas MD, Marschang RE, Schmidt V, Kasper A, Papp T. A unique novel reptilian paramyxovirus, four atadenovirus types and a reovirus identified in a concurrent infection of a corn snake (Pantherophis guttatus) collection in Germany. Vet Microbiol. 2011;150:70-9.

2. Ahne W, Batts WN, Kurath G, Winton JR. Comparative sequence analyses of sixteen reptilian paramyxoviruses. Virus Res. 1999;63:65-74.

3. Franke J, Essbauer S, Ahne W, Blahak S. Identification and molecular characterization of 18 paramyxoviruses isolated from snakes. Virus Res. 2001:80:67-74.

4. Hyndman TH, Shilton CM, Marschang RE. Paramyxoviruses in reptiles: A review. Vet Microbiol. 2013;165:200-13.

5. Kurath G, Batts WN, Ahne W, Winton JR. Complete genome sequence of Fer-de-Lance virus reveals a novel gene in reptilian paramyxoviruses. J Virol. 2004;78:2045-56.

6. Kurath G. https://talk.ictvonline.org/files/ictv_official_taxonomy_updates_since_ the_8th report/m/vertebrate-official/4161? Redirected=true. Accesed 3 Apr 17.

7. Manvell $R$, Geach M, Lewis J. Isolation of ophidian paramyxovirus type 7 from a reticulated python in the UK. Vet Rec. 2000;147:696.

8. Marschang RE, Papp T, Frost JW. Comparison of paramyxovirus isolates from snakes, lizards and a tortoise. Virus Res. 2009;144:272-9.

9. Oros J, Torrent A, Castro P, Deniz S, Casal A, Jacobson E, Homer B. Ophidian paramyxovirus in snakes in the Canary Islands: An Immunohistochemical Study. Vet Rec. 2001;149:21-3.

10. Papp T, Pees M, Schmidt V, Marschang RE. RT-PCR diagnosis followed by sequence characterization of paramyxovirus infections in clinical samples from snakes reveals concurrent infections within populations and/or individuals. Vet Microbiol. 2010;144:466-72.

11. Papp T, Gál J, Abbas MD, Marschang RE, Farkas FL. A novel type of paramyxovirus found in Hungary in a masked water snake (Homalopsis buccata) with pneumonia supports the suggested new taxonomy within the Ferlavirus genus. Vet Microbiol. 2013;162:195-200.

12. Pasmans F, Blahak S, Martel A, Pantchev N. Introducing reptiles into a captive collection: the role of the veterinarian. Vet J. 2008;175:53-68.

13. Pees M, Schmidt V, Marschang RE, Heckers KO, Krautwald-Junghanns ME. Pevalence of viral infections in captive collections of boid snakes in Germany. Vet Rec. 2010;166:422-5.

14. Samal S, Kumar S, Khattar SK, Samal SK. A single amino acid change, Q114R, in the cleveage-site sequence of Newcastle disease virus fusion protein attenuates viral replication and pathogenicity. J Gen Virol. 2011;92:2333-8.

15. Tamura K, Peterson D, Peterson N, Stecher G, Nei M, Kumar S. MEGA5 molecular evolutionary genetics analysis using maximum likelihood, evolutionary distance, and maximum parsimony methods. Mol Biol Evol. 2011;28:2731-9.

16. Thompson JD, Gibson TJ, Plewniak F, Jeanmougin F, Higgins DG. The CLUSTAL $X$ windows interface: flexible strategies for multiple sequence alignment aided by quality analysis tools. Nucleic Acids Res. 1997;25:4876-82.

\section{Submit your next manuscript to BioMed Central and we will help you at every step:}

- We accept pre-submission inquiries

- Our selector tool helps you to find the most relevant journal

- We provide round the clock customer support

- Convenient online submission

- Thorough peer review

- Inclusion in PubMed and all major indexing services

- Maximum visibility for your research

Submit your manuscript at www.biomedcentral.com/submit
Biomed Central 